\title{
Tissue-specific regulation of gastrin-releasing peptide synthesis, storage and secretion by oestrogen and progesterone
}

\author{
J C Whitley, A S Giraud ${ }^{1}$, A O Mahoney, I J Clarke ${ }^{2}$ \\ and A Shulkes
}

\author{
Department of Surgery, University of Melbourne, Austin and Repatriation Medical Centre, Austin Campus, Melbourne, Victoria 3084 Australia \\ ${ }^{1}$ Department of Medicine, University of Melbourne, Western Hospital, Footscray, Victoria, Australia \\ ${ }^{2}$ Prince Henry's Institute of Medical Research, Monash Medical Centre, Clayton, Victoria, Australia \\ (Requests for offprints should be addressed to J C Whitley; Email: janecw@austin.unimelb.edu.au)
}

\begin{abstract}
In the ovine endometrium, dramatic increases in gastrinreleasing peptide (GRP) mRNA and immunoreactivity are observed during the luteal regression phase of the oestrous cycle (24-fold) and during pregnancy (at least 150-fold). This study sought to determine whether oestrogen and/or progesterone were responsible for the temporal regulation of GRP observed in the uterus. Ovariectomized sheep were divided into four groups $(n=4)$, as follows: 1 , untreated; 2 , given subcutaneous and intravaginal progesterone implants; 3 , given subcutaneous oestrogen implants; and 4, treated with both oestrogen and progesterone. After 10 days, the animals were sacrificed and plasma, pituitary and endometrium were obtained. A fifth group of sheep with intact ovaries was included. Analysis of endometrial GRP-immunoreactivity (GRP-ir) revealed a twofold drop for groups treated with oestrogen, progesterone or both hormones. A dramatic reduction in endometrial GRP mRNA was observed in the group treated with both hormones. GRP-ir was measured in whole pituitaries and found to vary greatly $(1 \cdot 7-$
\end{abstract}

$53.7 \mathrm{pmol} / \mathrm{g}$ tissue) within all groups of ovariectomized animals. There were no significant differences between any of the five groups. A significant reduction in circulating GRP-ir was observed after 10 days of treatment with either oestrogen or progesterone. These studies demonstrate that, in sheep, the synthesis, storage and secretion of GRP are differentially affected by oestrogen and progesterone. Regulation appears to be tissue specific since GRP content in the pituitary is unchanged by oestrogen or progesterone whereas GRP expression in the endometrium is inhibited. Changes in GRP mRNA expression did not correlate with changes in endometrial expression of mRNA for oestrogen receptor alpha, oestrogen receptor beta and the progesterone receptor. This study is the first reported demonstration that expression of the GRP gene can be influenced by the presence of ovarian steroids, with the conclusion that oestrogen and/or progesterone act as negative regulators of endometrial GRP expression.

Journal of Endocrinology (2000) 166, 649-658

\section{Introduction}

There is now convincing evidence of a novel gastrinreleasing peptide (GRP)-like protein in the uterus - a most unexpected tissue for a protein that is generally regarded as a neurotransmitter. Traditionally, GRP is known for the ability to stimulate the release of gastrin and other gastrointestinal hormones in the gut (see Bunnett 1994 for a review). GRP is also found in the brain (Lynn et al. 1996), in pulmonary endocrine cells of the foetal lung (Spindel et al. 1987) and is produced by a variety of human tumours (Preston et al. 1996). Mitogenic effects of GRPlike peptides have been demonstrated for a number of different cell types, including Swiss 3T3 fibroblast cells (Zachary \& Rozengurt 1985), ovine foetal chondrocytes
(Hill \& McDonald 1992) and human endometrial stromal cells in culture (Endo et al. 1991).

For the ovine uterus, we have previously demonstrated temporal regulation of GRP throughout gestation and the oestrous cycle. Throughout the last third of gestation, GRP circulates in the foetus and in the mother at concentrations sufficient to activate GRP receptors (Giraud et al. 1993). These increases in circulating GRP peptide are accompanied by an increase in endometrial GRP mRNA of at least 150-fold (Whitley et al. 1994). During early pregnancy, secreted GRP peptide levels rise 10-fold just prior to implantation at day 17 whereas stored endometrial GRP and GRP mRNA increase 4- and 13-fold respectively between days 17 and 20 immediately following blastocyst attachment and corresponding to the 
onset of placentome development (Giraud et al. 1993). During the ovine oestrous cycle the expression of GRP is low at days 4, 10,12 and 14 and has increased at day 16; 5-fold and 24-fold rises are observed respectively for GRP peptide and GRP mRNA (Whitley et al. 1998). Increases in GRP peptide and mRNA are also observed in the pregnant human uterus at term (Whitley et al. 1996).

The pattern of GRP expression in the ovine endometrium during both the oestrous cycle and pregnancy suggests that expression of the GRP gene may be influenced by ovarian steroids. However, the pattern of progesterone release does not correspond with the pattern of GRP expression; at day 16 of the oestrous cycle, GRP mRNA and peptide levels are maximal and circulating progesterone is low, yet at day 20 of pregnancy both GRP mRNA and peptide are elevated when progesterone is high. The expression of GRP may be under the direct influence of oestrogen since the maximum level of GRP synthesis at day 16 of the oestrous cycle correlates with the pre-oestrous surge of oestrogen and also with the concentrations of oestrogen receptors in the superficial and deep glands of the sheep endometrium (Cherny et al. 1991), which we have previously shown to be the site of GRP mRNA synthesis (Whitley et al. 1998).

Few factors regulating expression of the GRP gene have been identified. Light exposure led to increased GRP content in the suprachiasmatic nucleus (Shinohara et al. 1993), food withdrawal and the acid-inhibitory drug omeprazole induced a fivefold increase in GRP mRNA in the gastric antrum (Dimaline et al. 1992) and retinoic acid was observed to lead to increased expression of GRP in small-cell lung cancer cell lines with functional retinoid signalling (Ravi et al. 1998). Effects of oestrogen or progesterone on GRP gene expression have not been reported, although some actions of GRP or the amphibian homologue bombesin have been shown to be modified in the presence of oestrogen. These include GRP mediation of endocrine activity by the pancreas and pituitary (Westendorf \& Schonbrunn 1982, Houghton et al. 1992, Houben \& Denef 1990) and GRP stimulation of smoothmuscle contractility (Stjernquist et al. 1986).

The observations of marked cyclical changes in GRP mRNA and protein throughout the ovine oestrous cycle and early pregnancy and of elevated GRP mRNA and protein in pregnant human and ovine uterine tissue led us to investigate the regulation of GRP gene expression by the sex steroid hormones oestrogen and progesterone. The model used for this study has been well defined (Salamonsen et al. 1991) and involved the removal of ovaries from non-pregnant, non-cycling sheep followed by subcutaneous or intravaginal insertion of implants containing oestrogen, progesterone or both hormones for a 10-day period. GRP gene expression was measured as steady-state levels of mRNA in endometrium and as protein content in endometrium and pituitary. Circulating levels of GRP- immunoreactivity (GRP-ir) were also measured. As a first step towards identification of the nuclear receptor involved in regulation of uterine GRP mRNA synthesis, the expression of oestrogen receptor alpha $(\mathrm{ER} \alpha)$, oestrogen receptor beta $(\mathrm{ER} \beta)$ and the progesterone receptor $(\mathrm{PR})$ in the ovine endometrium were monitored by semiquantitative RT-PCR and compared with changes in the expression of GRP mRNA (assessed by Northern analysis and RT-PCR).

\section{Materials and Methods}

\section{Animals}

For all animal experimentation, ethics approval was granted by the animal ethics committees of Prince Henry's Institute of Medical Research, Clayton and the Austin and Repatriation Medical Centre, Austin Campus, Victoria.

A group of 16 mature Corriedale ewes were selected from a uniform flock at the Animal Research Institute (Werribee, Victoria, Australia). The ewes were run under field conditions throughout the study. They were bilaterally ovariectomized via mid-ventral laparotomy and allowed to recover for 1 month before being divided into four groups ( $n=4$ in each group). Group 1 received two progesterone implants (Ceva Chemicals Australia Pty Ltd, Melbourne, Vic., Australia) inserted subcutaneously in the axilla for 10 days and also an intravaginal progesterone delivery device (CIDR; Riverina Artificial Breeders, Albany, NSW, Australia) for the last 5 days of treatment. Group 2 received $3.0 \mathrm{~cm}$ oestrogen subcutaneous implants for 10 days. Group 3 also received oestrogen subcutaneous implants for 10 days as well as intravaginal progesterone via CIDR for the last 5 days of the experiment. Group 4 was not given any steroid implants. A fifth group of nonpregnant, non-cycling sheep were included as ovary-intact controls $(n=4)$.

The subcutaneous implants are prepared by sealing one end of a $3.0 \mathrm{~cm}$ length of Silastic medical-grade tubing with a $0.5 \mathrm{~cm}$ plug of Silastic medical-grade elastomer. Crystalline oestradiol-17 $\beta$ or crystalline progesterone (both supplied by the Sigma Chemical Co., St Louis, MO, USA) was packed into the tube and the open end of the tube sealed as before. The capsules were implanted in the following manner: the site was infiltrated with local anaesthetic and an incision (1-2 cm in length) made in the previously shaved skin of the axillary region. A trochar containing an implant was inserted through the incision and pushed subcutaneous until the blunt tip of the trochar was approximately $10 \mathrm{~cm}$ from the incision where the implant was deposited; the incision was then closed with surgical silk. Previous studies have shown that this regimen produces physiological levels of oestrogen and progesterone in the blood that are similar to those measured during the luteal phase of the ovine oestrous cycle (Salamonsen 1986, Salamonsen et al. 1991). 
Table 1 Oligonucleotide primers used for the PCR and detection of ovine $\beta$-actin, GRP, ER $\alpha$, ER $\beta$ and PR mRNA. Forward and reverse PCR primers were designed to span an intron, except for ovine ER $\beta$ (in which the partial cDNA sequence was within a single exon). Exon boundaries were deduced by homology with an equivalent human gene sequence. Italics denote additional nucleotides. A Pstl restriction site is underlined. Primers were designed using the PRIMER3 software program (Rozen \& Skaletsky (2000) Primer 3; code available at http://www.genome.wi.mit.edu/genome_software/other/primer3.html)

GenBank locus

mRNA detected

$\beta$-Actin

GRP

$\mathrm{ER} \alpha$

ER $\beta$

PR

\section{OAU39357}

S75723

OAESTREC

AF110817

OAPROGREC

\section{Primer}

Forward: $\quad 5^{\prime}$ - TGGGAGCACATGGAGAAGATCTGGC- $3^{\prime}$ Reverse: 5'-CAGCACAGCCTGGATGGCCACGTAC- $3^{\prime}$ Probe: 5'-CCCAAGGCCAACCGTGAGAAGATGA - 3' Forward: 5'-CGCGCGGCAACCACTGGGCGGT - 3'

Reverse: 5'-GGCTGCAGGCTGGTGAATGCTCAGG - 3' Probe: $\quad 5^{\prime}$-GGGGACTCTGCCACACTCTT-3' Forward: $5^{\prime}$-CAGGGAGCTGGTACACATGA- $3^{\prime}$ Reverse: 5'-ACGGAACCGAGACGATGTAG-3' Probe: $\quad 5^{\prime}$-TGTGCCTGGCTAGAGATCCT- $3^{\prime}$ Forward: $\quad 5^{\prime}$ - CGAAGGCAGAGAAATTCTGA- $3^{\prime}$ Reverse: 5'-CATGGAGGCCTCAGTGAA- $3^{\prime}$ Probe: $\quad 5^{\prime}$-GCTGGTGCTTACTCTCCTGG- $3^{\prime}$ Forward: $\quad 5^{\prime}$-GGTGTCCTCACCTGTGGAAG- $3^{\prime}$ Reverse: $5^{\prime}$-CCAGCCTGACAGCACTTTCT- $3^{\prime}$ Probe: $\quad 5^{\prime}$-TGTGCTGGAAGAAACGATTG- $3^{\prime}$
Product size

(bp)

186
At day 10, the animal was euthanased with a lethal dose of barbiturate. A sample of endometrium was taken and assayed for GRP-ir and for GRP, ER $\alpha, E R \beta$ and PR mRNA. Whole pituitaries were removed and assayed for GRP-ir. Peripheral blood samples were taken at days 0, 5 and 10 for the measurement of plasma GRP.

\section{Isolation of RNA and Northern analysis for GRP $m R N A$ and $\beta$-actin $m R N A$}

Total RNA was isolated from endometrial tissues using Trizol reagent (Gibco-BRL, Mulgrave, Vic., Australia) as previously described (Whitley et al. 1999). Thirty micrograms of each RNA sample were separated by denaturing agarose gel electrophoresis prior to transfer to supported nitrocellulose membranes (Hybond C extra, Amersham, Melbourne, Vic., Australia). Northern analysis for GRP mRNA, using radiolabelled ovine GRP cDNA as the probe, was performed essentially as described previously (Giraud et al. 1994). A PCR product generated with primers specific for ovine $\beta$-actin cDNA (as described in Table 1 and in Whitley et al. 1999) was isolated, purified and radiolabelled for use as a probe in Northern analysis for $\beta$-actin mRNA. Hybridization conditions and washes were performed as described previously (Giraud et al. 1994). A specific hybridization signal was detected after autoradiography with XAR-5 film (Kodak, Coburg, Vic., Australia) using two intensifying screens and storage at $-70{ }^{\circ} \mathrm{C}$. GRP mRNA was quantified by laser densitometry (LKB Ultroscan XL enhanced laser densitometer, LKB/AMRAD, Kew, Vic., Australia) and loading was corrected with reference to the amount of $\beta$-actin mRNA.
Large variations in GRP-ir in portions of isolated pituitaries necessitated the measurement of GRP-ir from whole pituitary samples.

Measurement of GRP, ER $\alpha, E R \beta$ and $P R m R N A$ by RT-PCR

Preparation of poly(A)+ RNA Poly(A)+ RNA was purified from $75 \mu \mathrm{g}$ total RNA using $1 \mathrm{mg}$ oligo dTlinked magnetic beads (Dynabeads) according to the manufacturer's instructions (Dynal, Clifton Hill, Vic., Australia). Following elution of the poly(A)+ RNA in $20 \mu 10 \mathrm{~mm}$ Tris-HCl (pH 7.5) the used beads were pooled and regenerated for reuse by treatment with $0 \cdot 1 \mathrm{M}$ $\mathrm{NaOH}$ according to the manufacturer's instructions. Regenerated beads were used a further three times and then discarded. A portion (1/10th) of the eluted poly (A)+ RNA was subject to denaturing agarose gel electrophoresis and Northern hybridization with a radiolabelled ovine $\beta$-actin cDNA probe to check the integrity of the prepared RNA.

cDNA synthesis and PCR Approximately $100 \mathrm{ng}$ poly(A)+ RNA and $4 \mathrm{ng} \mathrm{pdN}_{6}$ were used for cDNA synthesis with Superscript reverse transcriptase according to the manufacturer's instructions (Gibco-BRL, Life Technologies, Mount Waverly, Vic., Australia). The cDNA $(1 \mu \mathrm{l}$ was equivalent to approximately $5 \mathrm{ng}$ poly(A)+ RNA) was tested as a viable template for the PCR by using primers designed to detect the ovine $\beta$-actin gene (see Table 1 ) and 30 cycles of $95^{\circ} \mathrm{C}$ for $30 \mathrm{~s}$, $55{ }^{\circ} \mathrm{C}$ for $30 \mathrm{~s}$, and $72{ }^{\circ} \mathrm{C}$ for $30 \mathrm{~s}$. The PCR consisted of $2 \mathrm{U}$ Taq polymerase (Geneworks, Adelaide, SA, 
Australia), $100 \mathrm{ng}$ each of the forward and reverse primers (Table 1), $1.5 \mathrm{mM} \mathrm{MgCl} 2,200 \mu \mathrm{M}$ of each deoxyribonucleic triphophate (dATP, dCTP, dGTP, dTTP), $1 \times$ Taq polymerase buffer (supplied by the manufacturer) in a $50 \mu \mathrm{l}$ reaction volume. The PCR was performed for GRP, ER $\alpha, E R \beta$ and PR with $5 \mu 1$ sample aliquots removed at the end of 25, 30 and 35 cycles (GRP), at the end of 22, 25 and 28 cycles (ER $\alpha$ ), at the end of 27, 30 and 33 cycles $(\mathrm{ER} \beta)$ or at the end of 24,27 and 30 cycles (PR) in an attempt to visualize PCR products during the linear stages of amplification. This enabled a semi-quantitative comparison of mRNA expression in ovine endometrium undergoing different treatments. Ovine-specific oligonucleotides used for the PCR and hybridization are described in Table 1. Reaction conditions were the same as described above for $\beta$-actin except for the addition of 0.5 U uracil-N-glycosylase (UNG) (Roche, Castle Hill, NSW, Australia) and the substitution of dUTP for dTTP in PCR for the steroid receptors (to prevent contamination by previously amplified product). In the PCR using UNG, pre-amplification incubations at $37^{\circ} \mathrm{C}(10 \mathrm{~min})$ and $94{ }^{\circ} \mathrm{C}(10 \mathrm{~min})$ were included for cleavage of any dUTP-containing contaminating amplified material and for inactivation of the UNG respectively. Upon completion of amplification, UNG-containing samples were kept at $72{ }^{\circ} \mathrm{C}$ or stored at $-20{ }^{\circ} \mathrm{C}$ prior to electrophoretic analysis (to prevent UNG degradation of the desired product). Negative controls in which $1 \mu \mathrm{l}$ water was substituted for $1 \mu \mathrm{l}$ cDNA were included in all PCRs.

PCR products were separated by electrophoresis through $2 \%$ agarose in $0.5 \times \mathrm{TAE}(40 \mathrm{~mm}$ Tris-acetate, $1 \mathrm{~mm}$ EDTA, $\mathrm{pH} \mathrm{8)}$ and visualized by staining with ethidium bromide $(0.5 \mu \mathrm{g} / \mathrm{ml})$ prior to capillary transfer to a nylon membrane (Hybond $\mathrm{N}^{+}$, Amersham, North Ryde, NSW, Australia) in $0.4 \mathrm{M} \mathrm{NaOH}$. Oligonucleotide probes (Table 1) for Southern hybridization were prepared using $50 \mu \mathrm{Ci} \quad\left[{ }^{32} \mathrm{P}\right] \mathrm{dCTP} \quad(3000 \mathrm{Ci} / \mathrm{mmol}$; Geneworks) and $50 \mathrm{U}$ terminal transferase, according to the instructions of the manufacturer (Roche, Castle Hill, NSW, Australia). Hybridization was effected in the presence of RapidHyb hybridization buffer (Amersham) at $42{ }^{\circ} \mathrm{C}$ for $1 \mathrm{~h}$. Unhybridized probe was removed by rinsing the membranes twice in $0.1 \times$ SCC (standard saline citrate) $/ 0 \cdot 1 \%(\mathrm{w} / \mathrm{v})$ SDS and washing twice for 15 min at $42{ }^{\circ} \mathrm{C}$ in the same solution. An LKB Ultroscan $\mathrm{XL}$ enhanced laser densitometer was used to quantifiy the $\mathrm{ER} \alpha$ product (at 22 cycles) and $\mathrm{ER} \beta$ and PR (at 27 cycles).

\section{Radioimmunoassay}

GRP-ir was measured by a previously described radioimmunoassay (RIA) (Giraud et al. 1994) using polyclonal antiserum R40 raised against $\left[\mathrm{Lys}^{3}\right]$-bombesin (kindly donated by Professor B Jarrott, Department of Pharmacology, Monash University, Melbourne, Australia). The
RIA uses ${ }^{125}$ I-labelled $\mathrm{Tyr}^{4}$ bombesin as the tracer. The assay diluent was $0.7 \mathrm{ml} 25 \mathrm{mM}$ phosphate buffer, $0.1 \%$ BSA and $2 \mu \mathrm{M} \mathrm{NaN}$, to which were added $100 \mu$ label (5000 c.p.m.), $100 \mu \mathrm{l}$ antibody R40 (1:100 000 final concentration) and $100 \mu \mathrm{l}$ sample or standard. Tubes were incubated for $48 \mathrm{~h}$ at $4{ }^{\circ} \mathrm{C}$ and bound counts were separated from free counts by the addition of $300 \mu \mathrm{l}$ of a cocktail consisting of equal volumes of goat anti-serum immunoglobulin $G$ (plasma diluted 1:60 in assay buffer), non-immune rabbit plasma (1:600), and polyethylene glycol $(10 \%)$, followed by centrifugation $(2000 \times \mathbf{g}$, $30 \mathrm{~min})$. Non-specific binding was $1 \cdot 5 \pm 0 \cdot 09 \%(n=47)$. The RIA standard was bombesin $(3 \cdot 9-1000 \mathrm{fmol} / \mathrm{ml})$; $50 \%$ inhibition of label binding occurred at $125 \pm 7 \mathrm{fmol} /$ $\mathrm{ml}(n=48)$. Inter- and intra-assay coefficients of variation were $14 \%$ and $4 \%$ respectively. The antiserum is directed to the amidated carboxyl terminus and cross-reacts $100 \%$ with bombesin, $\left[\mathrm{Tyr}^{4}\right]$-bombesin, GRP-(18-27) and GRP-(1-27) and less than 0.1\% with neuromedin B and substance $\mathrm{P}$. The detection limit per assay tube was $4 \mathrm{fmol} / \mathrm{ml}$.

\section{Statistical analysis}

The data for GRP-ir and GRP mRNA in endometrium were analysed by one-way ANOVA followed by the Student-Newman-Keuls method for all pairwise multiple comparisons. Data for pituitaries failed the normality test and were subsequently analysed by Kruskal-Wallis oneway ANOVA. Data for GRP-ir in plasma on days 0,5 and 10 were analysed separately for each group (i.e. ovariectomized, oestrogen-treated, progesterone-treated, EPtreated) by one-way ANOVA followed by the StudentNewman-Keuls method for all pairwise multiple comparisons if warranted. Data for steroid receptor expression were analysed by one-way ANOVA followed by Dunnett's method for comparison with a control. These analyses were performed using SIGMASTAT statistical software (Jandel Scientific, San Rafael, CA, USA). P $<0 \cdot 05$ was accepted as significant. Data are presented as the means \pm s.E.M. values.

\section{Results}

\section{GRP $m R N A$ in endometrium}

The expression of GRP mRNA and $\beta$-actin mRNA in endometrium was examined by Northern analysis (Fig. 1A). Using ovine GRP as the probe, an mRNA transcript of approximately $1 \mathrm{~kb}$ was identified in all samples of endometrium taken from non-pregnant (NP) animals, ovariectomized $(\mathrm{Ox})$ animals and from ovariectomized animals treated with either oestrogen or progesterone. Substantial variation in the signal was observed between samples (each representing tissue taken from a different 
A

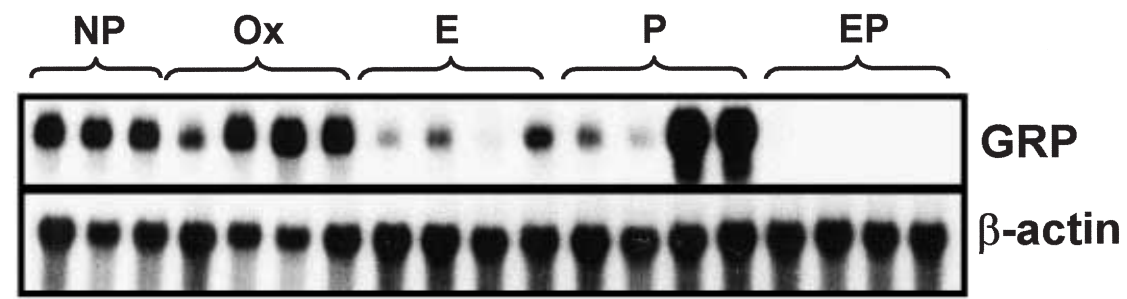

B

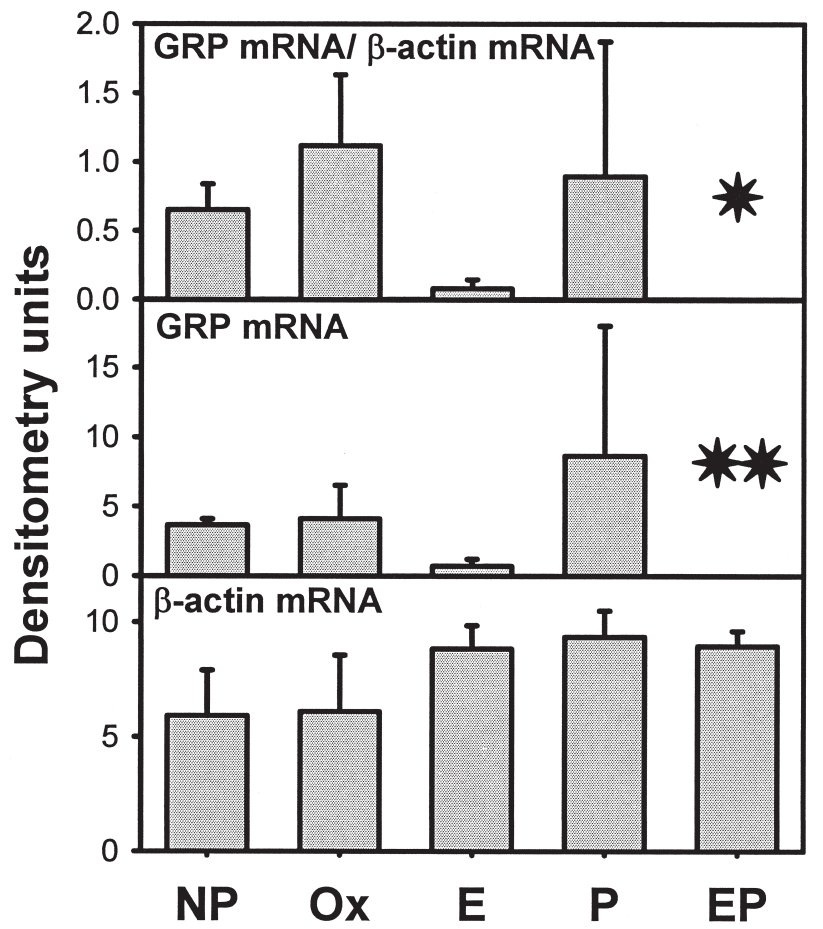

Figure 1 Expression of GRP and $\beta$-actin mRNA in ovine endometrium isolated from animals that were non-pregnant non-cycling (NP), untreated ovariectomized (Ox), ovariectomized and treated with oestrogen $(E)$, ovariectomized and treated with progesterone $(P)$ or ovariectomized and treated with both oestrogen and progesterone (EP). (A) Total RNA $(30 \mu \mathrm{g})$ from each sample was subjected to low-formaldehyde agarose gel electrophoresis and Northern hybridization for GRP mRNA followed by removal of radiolabelled probe from the membrane and reprobing for $\beta$-actin mRNA expression. (B) Densitometric representation of GRP expression normalized to $\beta$-actin expression and of GRP mRNA and $\beta$-actin mRNA individually. ${ }^{*}$ Significantly different from $\mathrm{Ox}$ and $\mathrm{P}(P=0 \cdot 008) ;{ }^{* *}$ significantly different from NP, Ox and $\mathrm{P}(P=0 \cdot 013)$.

animal) in the oestrogen or progesterone single-treatment groups. GRP mRNA was not observed in any of the four animals undergoing combined treatment with both oestrogen and progesterone (EP). Densitometric representation of the expression of GRP mRNA normalized to the relatively invariant $\beta$-actin mRNA (Fig. 1B) and statistical analysis confirmed a significant difference for GRP mRNA synthesis in the endometrium of animals in the EP group compared with the NP, Ox and progesterone groups of animals $(P=0 \cdot 013)$. There were no significant differences in GRP mRNA steady-state levels between the NP, Ox, oestrogen or progesterone groups. No GRP mRNA was observed under these Northern analysis conditions in the EP group (Fig. 1A), although faint bands were seen after longer autoradiographic exposure (data not shown). PCR confirmed the substantial decrease in GRP mRNA expression in endometrium isolated from the EP group (Fig. 2). The PCR product was removed after 25 , 30 and 35 cycles and subjected to electrophoresis and subsequent Southern hybridization with an oligonucleotide probe internal to the two GRP PCR primers (Table 1). As seen in Fig. 2, after 25 cycles the GRP PCR product was not observed in the EP group but was present for all other groups at relative amounts similar to the results obtained from Northern analysis (Fig. 1A). After 30 cycles, product was observed for all samples and appeared to have reached a maximum (i.e. the plateau phase of the PCR) for cDNA samples isolated from the NP, Ox and 


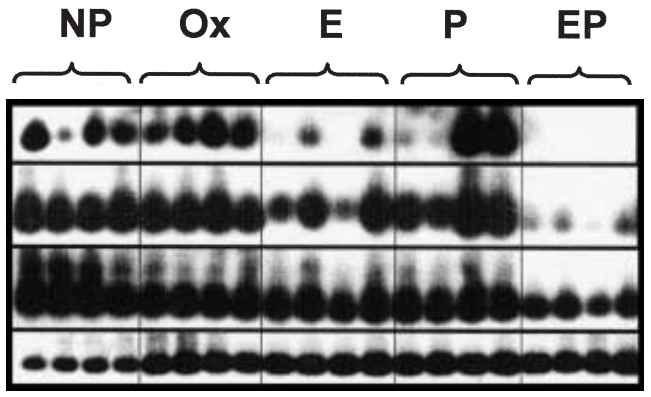

$25 x$

$30 x$

$35 x$

Figure 2 RT-PCR-detected expression of GRP mRNA in endometrium. cDNA was prepared from poly $(\mathrm{A})+\mathrm{RNA}$ isolated from endometrium from NP, Ox, E, P or EP animals (abbreviations are as defined in Fig. 1). For GRP, PCR samples (1/10th reaction) were removed after 25, 30 and 35 cycles, subjected to agarose gel electrophoresis and the products visualized by Southern hybridization with radiolabelled oligonucleotide. The PCR product for $\beta$-actin resulting from 30 cycles of amplification is also shown.

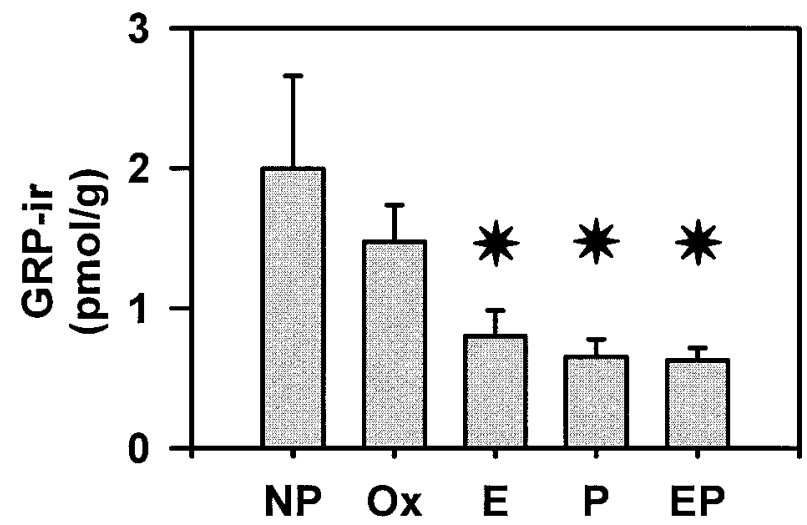

Figure 3 GRP-ir (pmol/g) in endometrial tissue samples taken from $\mathrm{NP}, \mathrm{Ox}, \mathrm{E}, \mathrm{P}$ or EP animals (abbreviations are as defined in Fig. 1).

*Significantly different from NP and Ox $(P=0 \cdot 019)$.

progesterone groups. At the 30-cycle stage, only samples prepared from endometrium isolated from the EP animals appeared to represent the linear phase of PCR product accumulation. At 35 cycles, the PCR product for all samples had reached the plateau stage (Fig. 2).

\section{GRP-ir in endometrial tissue}

GRP-ir was low (less than $3 \mathrm{pmol} / \mathrm{g}$ ) in all samples of endometrium (Fig. 3). No significant differences were observed in GRP-ir for endometrium isolated from the $\mathrm{NP}$ and Ox groups. A twofold reduction in GRP-ir $(P=0 \cdot 019)$ was observed for endometrial extracts taken from animals treated with steroid hormones alone or in combination (i.e. the oestrogen, progesterone and EP groups) compared with extracts taken from the NP or Ox animals.

\section{GRP-ir in pituitary}

To counteract the heterogeneous distribution of GRP-ir throughout the pituitary, the whole pituitary was used for

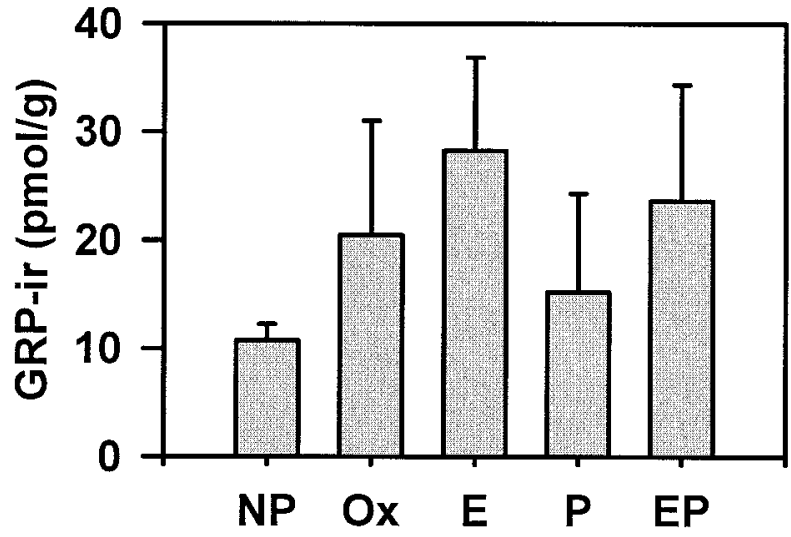

Figure 4 GRP-ir (pmol/g) in pituitary samples taken from NP, Ox, $\mathrm{E}, \mathrm{P}$ or EP animals (abbreviations are as defined in Fig. 1). No significant differences were observed.

determination of the level of GRP-ir (pmol/g). No significant differences in GRP-ir were found in pituitaries isolated from any group of animals (Fig. 4). A small amount of variance for GRP-ir data was observed within the NP group, whereas large differences were observed within the groups of untreated and treated ovariectomized animals (Fig. 4). No statistically significant differences between any groups were obtained for weights of whole pituitaries or for total GRP-ir per pituitary (data not shown).

\section{GRP-ir in plasma}

GRP-ir was measured in plasma taken at days 0, 5 and 10 from untreated and treated ovariectomized animals and found to be low for all samples (Fig. 5). No change in GRP-ir was observed in plasma from the Ox or EP groups of animals. A significant $(P=0.003)$ fourfold reduction in plasma GRP-ir was observed for ovariectomized animals following $10 \mathrm{~d}$ progesterone treatment (Fig. 5). A similar fall in GRP-ir was observed in the day 10 sample taken from oestrogen-treated ovariectomized sheep $(P=0 \cdot 05)$. The combination of oestrogen and progesterone did not alter the circulating GRP concentration.

\section{Steroid receptor expression}

A semi-quantitative PCR was used to determine the expression of $\mathrm{ER} \alpha, \mathrm{ER} \beta$ and $\mathrm{PR}$ in endometrium taken from ovary-intact (non-pregnant) sheep and from steroid hormone-treated and -untreated ovariectomized sheep (Fig. 6). Endometrial ER $\alpha$ mRNA expression in the Ox group was significantly lower $(P=0.034)$ than that in the NP-, oestrogen- and EP-treated groups (Fig. 6A and D). Expression of ER $\beta$ mRNA was increased for the EP group compared with the progesterone group only $(P=0 \cdot 051)$, whereas PR mRNA expression was significantly increased 


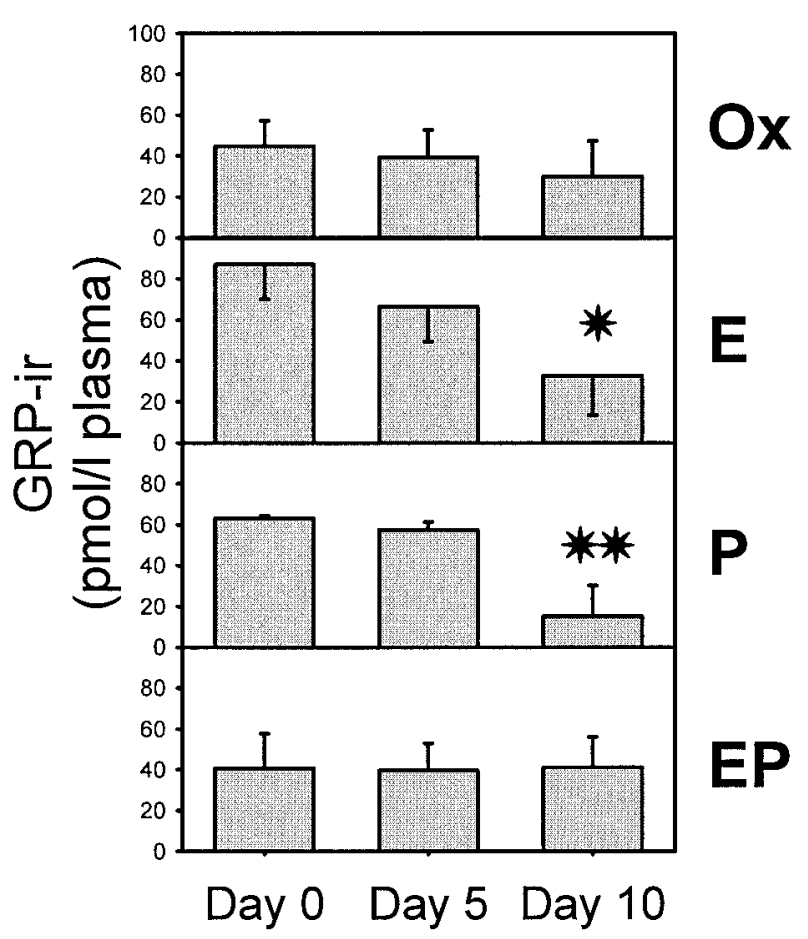

Figure 5 GRP-ir (pmol/l) in plasma taken from Ox animals at days 0 (Day 0), 5 (Day 5) and 10 (Day 10) of treatment with E, P or both (EP). Samples were also taken at similar times from a group of untreated Ox animals. (Abbreviations are as defined in Fig. 1.) ${ }^{*} P=0.05$ compared with Day $0 ;{ }^{* *} P=0.003$ compared with Day 0 .

for oestrogen-treated ovariectomized animals compared with all other treatment groups $(P=0 \cdot 007)$.

\section{Discussion}

In this study we have shown for the first time that oestrogen and progesterone have a role in the regulation of uterine GRP synthesis, storage and secretion. GRP mRNA steady-state levels in the endometrium of ovariectomized animals were dramatically reduced by combined treatment with oestrogen and progesterone but were not affected by treatment with oestrogen or progesterone individually. GRP peptide concentrations in the endometrium were reduced upon treatment with oestrogen and progesterone alone or in combination. In contrast, the GRP peptide content in the pituitary was not altered by any treatment regimen, indicating tissue-specific regulation of GRP expression by oestrogen and progesterone. Secretion of GRP into the peripheral circulation was found to be reduced by treatment with oestrogen or progesterone alone. Reduced endometrial expression of GRP mRNA in the animals treated with both oestrogen and progesterone did not correlate with changes in endometrial expression of $\mathrm{PR}, \mathrm{ER} \alpha$ or $\mathrm{ER} \beta$, possibly indicating an indirect mechanism for steroid hormone inhibition of GRP mRNA synthesis.

Our previous studies revealed temporal variation in endometrial GRP expression which did not correlate consistently with known changes in oestrogen and progesterone release. These studies showed little or no expression of GRP during the first $14 \mathrm{~d}$ of the oestrous cycle, followed by increases of 5-fold and 24-fold in GRP peptide and mRNA respectively between days 14 and 16 (Whitley et al. 1998). This period corresponds with regression of the corpus luteum, a subsequent fall in circulating progesterone levels and the pre-oestrous surge of oestrogen, suggesting either an inhibitory effect of progesterone or a stimulatory effect of oestrogen on the expression of endometrial GRP. In early pregnancy, GRP mRNA and peptide levels continue to increase with increasing progesterone until the end of pregnancy (Giraud et al. 1993, 1996) when there is at least a 150-fold difference in GRP mRNA levels between non-pregnant and pregnant endometrium (Whitley et al. 1994). Thus, inconsistent correlations were observed between endometrial GRP expression and oestrogen and progesterone levels. The present study revealed that in the ovariectomized ewe the addition of oestrogen or progesterone alone did not have any effect on endometrial GRP mRNA synthesis; however, oestrogen and progesterone in combination led to an enormous reduction in endometrial GRP mRNA compared with that of non-pregnant or untreated ewes. This was confirmed by both Northern analysis and RT-PCR. Substantial variation in endometrial GRP mRNA expression in response to oestrogen or progesterone alone was observed and is similar to the individual variation seen in the ovine endometrium during the oestrous cycle and early pregnancy (Whitley et al. 1998). In contrast, the low levels of endometrial GRP mRNA expression after combined EP treatment were consistent between animals and may reflect a stable regulatory response to the presence of both hormones. A small but significant reduction (approximately twofold) in tissue-stored GRP peptide resulted from both combined and single hormone treatments and suggests multiple regulatory effects of oestrogen and/or progesterone, at different stages of GRP gene expression, similar to that observed for several other genes (see Fuller 1991 for a review). The absence of a consistent correlation between the effects on GRP mRNA and protein levels with the different treatments supports the general hypothesis that protein expression cannot be deduced simply from mRNA transcript analysis as this fails to account for the multiple regulatory steps of gene expression (Gygi et al. 1999).

We have previously demonstrated that GRP is synthesized in the glandular epithelium (Whitley et al. 1998) and is secreted into the compartments of the uteroplacental unit and into the peripheral circulation (Giraud et al. 1993). In the model used in this study, we found a significant reduction in the levels of circulating GRP-ir for 
A

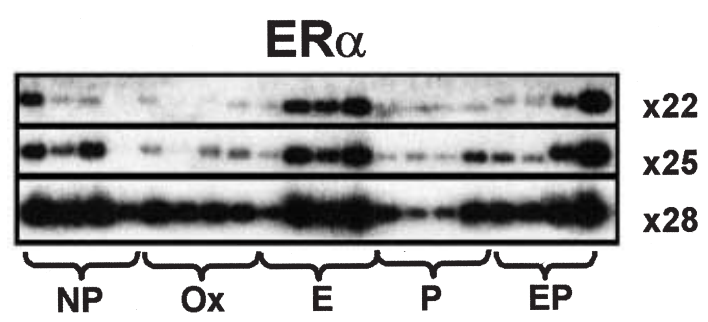

B

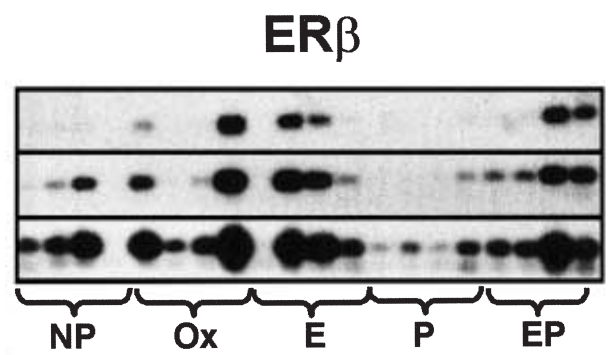

C

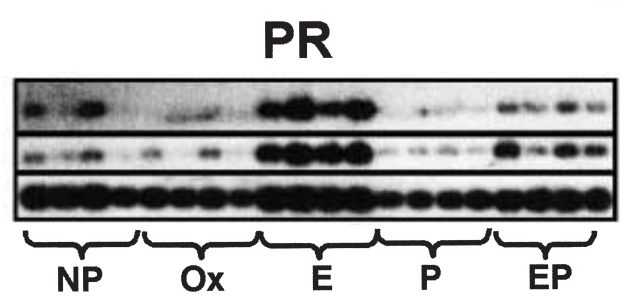

D

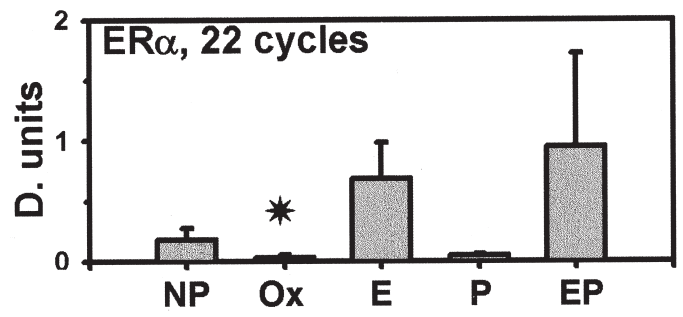

$\mathbf{E}$

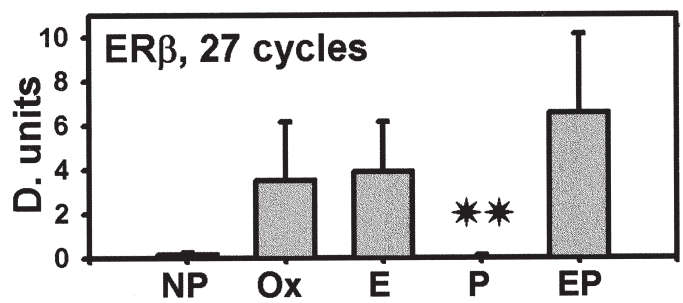

$\mathbf{F}$

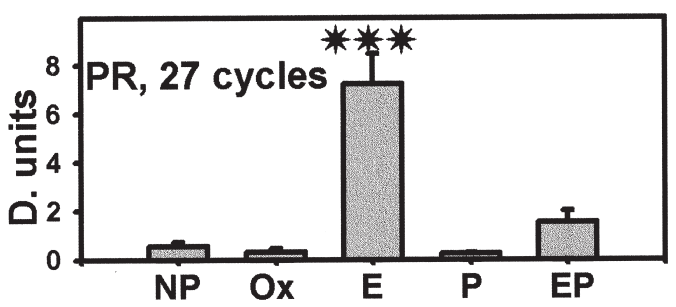

Figure 6 Semi-quantitative RT-PCR showing hybridization of specific PCR products and densitometric representation of product at the linear stage of amplification respectively for $\operatorname{ER} \alpha(A, D), E R \beta(B, E)$ and $P R(C, F) m R N A$ in endometrial tissue samples taken from NP, Ox, $\mathrm{E}, \mathrm{P}$ or $\mathrm{EP}$ animals (abbreviations are as defined in Fig. 1 ). ${ }^{*} P=0.034$ compared with $\mathrm{NP}, \mathrm{E}$ and $\mathrm{EP} ;{ }^{* *} P=0.051$ compared with $\mathrm{EP}$; ${ }^{* * *} P=0.007$ compared with NP, Ox, P and EP.

ovariectomized ewes treated with oestrogen and progesterone. Since combined oestrogen/progesterone treatment results in a dramatic reduction and single steroid hormone treatment is without effect on endometrial GRP mRNA synthesis, our observations of reduced GRP-ir in the circulation could suggest steroid hormone regulation, at the level of endometrial GRP secretion, by the glandular epithelial cells. It is unlikely that GRP secretion from other tissues may be regulated since GRP in the adult is localized almost exclusively in neurons (Bunnett 1994).

In the uterus, many physiological processes are regulated by oestrogens and progesterones, oestrogen being stimulatory for many uterotropic responses and progesterones usually being antagonistic (Clark \& Markaverich 1988). These effects are mediated by the ER and the PR and involve receptor-ligand-DNA interaction (Fuller 1991). The well-defined ER $\alpha$ is involved mainly in reproductive events whereas the more recently identified ER $\beta$ plays an important role in the physiology of several tissues. Reports to date indicate that ER $\alpha$ and $\operatorname{ER} \beta$ have different, and sometimes even opposite, biological functions (Gustafsson 1999). In this study, we also examined the expression of endometrial $\operatorname{ER} \alpha, \operatorname{ER} \beta$ and PR mRNA. Ovine endometrial ER $\alpha$ and PR mRNA expression was stimulated by oestrogen treatment and was consistent with previous findings (Ing \& Ott 1999). For both ER $\alpha$ and PR, progesterone was without effect. Combined treatment with oestrogen and progesterone did not antagonize the stimulatory effect of oestrogen alone for ER $\alpha$ mRNA expression. In contrast, for PR mRNA expression, combined treatment with both oestrogen and progesterone did antagonize the stimulatory effects of oestrogen, in agreement with previous observations (Wathes et al. 1996). In this study (the first reported attempt to examine steroid regulation of $\operatorname{ER} \beta$ mRNA expression in the endometrium), we observed that the inhibitory effect of progesterone was antagonized by combined steroid hormone treatment. Examination of $\operatorname{ER} \alpha, \operatorname{ER} \beta$ and PR mRNA expression relative to GRP mRNA expression in endometria isolated from each of the treatment groups 
reveals no correlation. Thus the molecular mechanism by which steroids modulate the expression of GRP mRNA in the endometrium is unclear; this suggests that oestrogen and progesterone may be acting via other factors rather than acting directly on the expression of the endometrial GRP gene.

Until now, the effects of oestrogen and progesterone on the regulation of GRP mRNA synthesis in any tissue or cell system have not been examined. However, there have been a number of reports demonstrating that several biological roles of GRP, including mediation of endocrine activity by the pancreas and pituitary and the stimulation of smooth-muscle contractility, are modified by the steroid environment. Treatment with oestradiol resulted in increased bombesin-stimulated prolactin release in rat pituitary GH4C1 clonal cells (Westendorf \& Schonbrunn 1982) and a 4-10-fold increase in bombesin-stimulated growth hormone release in rat pituitary cell aggregates (Houben \& Denef 1990). Oestrogen and progesterone treatment of ovariectomized sheep led to a decrease in the insulin response to GRP so that it was similar to that observed during pregnancy (Houghton et al. 1992), suggesting that GRP has a role in mediating pancreatic endocrine activity and that this is modified by the steroid environment of pregnancy. In oestrogen-treated rats, the bombesin-induced concentration-dependent clonic contractions in uterus and cervix were more pronounced but the frequency of spontaneous contractions and the smoothmuscle response were diminished (Stjernquist et al. 1986). It is not known whether these modulations of GRP activity by oestrogen in pituitary, pancreas or smooth muscle are a direct effect of the oestrogen-oestrogen receptor complex on GRP gene transcription. One study was unable to detect any effect of oestrogen on GRP mRNA synthesis in the rat anterior pituitary (partly because the baseline expression was very low) but was able to demonstrate a fivefold increase in mRNA of the GRP receptors (GRP-R), suggesting that in the pituitary, at least, a modulating effect of oestrogen on GRP activity is at the level of GRP-R gene transcription. In the present study, we were unable to examine the regulation of GRP-R gene expression in the pituitary but our preliminary studies suggest that GRP-R mRNA expression is not affected by oestrogen treatment in the ovine endometrium.

The control of GRP gene expression has not been well studied and few regulatory factors have been identified. Food withdrawal and omeprazole alone or in combination were shown to lead to threefold and fivefold increases respectively in GRP mRNA in rat gastric antrum and was without effect in the gastric corpus (Dimaline et al. 1992). In the suprachiasmatic nucleus of the rat, light was found to stimulate increases in GRP-ir (Shinohara et al. 1993) and GRP mRNA (Albers et al. 1991). Retinoic acid was found to lead to an increase in the expression of GRP in small-cell lung cancer cell lines with functional retinoid signalling, suggesting that the retinoic acid receptor is a ligand-inducible transcription factor for GRP gene expression (Ravi et al. 1998). Deletion analysis and transient expression of $6 \mathrm{~kb}$ of the $5^{\prime}$ flanking region of the GRP gene revealed a negative regulatory element, a general enhancer element and a tissue-specific element, however, the corresponding transcription factors were not identified (Nagalla \& Spindel 1994). Our preliminary analysis of the nucleotide sequence for the human GRP gene promoter (Nagalla \& Spindel 1994, GenBank Locus S73265) using the MATINSPECTOR V2.2 program and the TRANSFAC database (http://transfac.gbf.de/) to search for potential transcription factor binding sites revealed no ER or PR response elements. The present study suggests that oestrogen and progesterone alone and particularly in combination have a role in down-regulating expression of the ovine GRP gene. The lack of ER and PR response elements in the human GRP gene promoter may be due to the response elements being located elsewhere or could suggest that oestrogen and progesterone are acting indirectly. The factors that up-regulate the GRP gene in the ovine endometrium during luteal regression and pregnancy have yet to be identified.

This report presents the first evidence that oestrogen and progesterone are involved in the regulation of GRP gene expression in any tissue. This study suggests that oestrogen or progesterone is involved in down-regulation of endometrial GRP gene expression observed during the mid-luteal oestrous cycle but are not responsible for the large induction of GRP gene expression that takes place during the luteolytic phase of the oestrous cycle and the pre- and post-implantation stages of early pregnancy. Elucidation of the nature of the regulatory mechanisms will require molecular analysis of the, as yet uncharacterized, ovine GRP gene promoter and 5' flanking region.

\section{Acknowledgements}

This project is funded by the National Health and Medical Research Council of Australia. We gratefully acknowledge the assistance of Lorraine Parker with GRP RIAs, Sister Josephine Baker, Karen Hull and Bruce Doughton with the animal studies, and Peter Fuller for helpful discussions.

\section{References}

Albers HE, Liou SY, Ferris CF, Stopa EG \& Zoeller RT 1991 Neurochemistry of circadian timing. In Suprachiasmatic nucleus, pp 263-288. Eds DC Klein, RY Moore \& SM Reppert. New York: Oxford University Press.

Bunnett N 1994 Gastrin releasing peptide. In Gut Peptides: Biochemistry and Physiology, pp 423-445. Eds JH Walsh \& GJ Dockray. New York: Raven Press.

Cherny RA, Salamonsen LA \& Findlay JK 1991 Immunocytochemical localization of oestrogen receptors in the endometrium of the ewe. Reproduction, Fertility and Development 3 321-331. 
Clark JH \& Markaverich BM 1988 Actions of ovarian steroid hormones. In The Physiology of Reproduction, vol 1, pp 675-724. Eds E Knobil, JD Neill, LL Ewing, GS Greenwald, CL Markert \& DW Pfaff. New York: Raven Press.

Dimaline R, Sandvik AK, Barclay G \& Dockray GJ 1992 Functional control of gastrin releasing peptide (GRP) mRNA in rat stomach. FEBS Letters 301 291-293.

Endo T, Watanabe H, Yamamoto H, Tanaka S \& Hashimoto M 1991 Bombesin and bradykinin increase inositol phosphates and cytosolic free $\mathrm{Ca}^{2+}$, and stimulate DNA synthesis in human endometrial stromal cells. Journal of Endocrinology 131 313-318.

Fuller PJ 1991 The steroid receptor superfamily: mechanisms of diversity. FASEB Journal 5 3092-3099.

Giraud A, Parker L, Taupin D, Hardy K \& Shulkes A 1993 Mammalian bombesin as a hormone in ovine pregnancy: ontogeny, origin, and molecular forms. American Journal of Physiology 265 E866-E873.

Giraud A, Salamonsen L, Whitley J \& Shulkes A 1994 A peptide related to gastrin releasing peptide is synthesized and secreted by the ovine endometrium in early pregnancy. Endocrinology $\mathbf{1 3 5}$ 2806-2809.

Giraud A, Whitley J, Shulkes A \& Parker L 1996 The pregnant ovine endometrium constitutively expresses and secretes a highly stable bombesin-like peptide, which shares C-terminal sequence but differs structurally from gastrin-releasing peptide. Biochimica Biophysica Acta 1296 189-197.

Gustafsson J-Å 1999 Estrogen receptor $\beta$ - a new dimension in estrogen mechanism of action. Journal of Endocrinology 163 379-383.

Gygi SP, Rochon Y, Franza BR \& Aebersold R 1999 Correlation between protein and mRNA abundance in yeast. Molecular and Cellular Biology 19 1720-1730.

Hill DJ \& McDonald TJ 1992 Mitogenic action of GRP on isolated epiphyseal growth plate chondrocytes from the ovine fetus. Endocrinology $1302811-2819$.

Houben H \& Denef C 1990 Stimulation of growth hormone and prolactin release from rat pituitary cell aggregates by bombesin- and ranatensin-like peptides is potentiated by estradiol, 5 alphadihydrotestosterone, and dexamethasone. Endocrinology 126 2257-2266.

Houghton PE, McDonald TJ \& Challis JR 1992 Diminished insulinotropic effects of gastrin-releasing peptide in pregnant sheep are reproduced by progesterone treatment of nonpregnant animals. Endocrinology $1312337-2343$.

Ing NH \& Ott TL 1999 Estradiol up-regulates estrogen receptor-alpha messenger ribonucleic acid in sheep endometrium by increasing its stability. Biology of Reproduction 60 134-139.

Lynn RB, Hyde TM, Cooperman RR \& Miselis RR 1996 Distribution of bombesin-like immunoreactivity in the nucleus of the solitary tract and dorsal motor nucleus of the rat and human: colocalization with tyrosine hydroxylase. Journal of Comparative Neurology $369552-570$.

Nagalla SR \& Spindel ER 1994 Functional analysis of the $5^{\prime}$-flanking region of the human gastrin-releasing peptide gene in small cell lung carcinoma cell lines. Cancer Research 54 4461-4467.

Preston SR, Miller GV \& Primrose JN 1996 Bombesin-like peptides and cancer. Critical Reviews in Oncology-Hematology 23 225-238.
Ravi RK, Scott FM, Cuttitta F, Weber E, Kalemkerian GP, Nelkin BD \& Mabry M 1998 Induction of gastrin releasing peptide by all-trans retinoic acid in small cell lung cancer cells. Oncology Reports 5 497-501.

Rozen S \& Skaletsky H 2000 Primer3 on the WWW for general users and for biologist programmers. Methods in Molecular Biology 132 365-386.

Salamonsen LA 1986 Control of endometrial protein secretion during early pregnancy in the ewe. PhD Thesis. Monash University, Australia.

Salamonsen LA, Hampton AL, Clements JA \& Finday JK 1991 Regulation of gene expression and cellular localization of prostaglandin synthase by oestrogen and progesterone in the ovine uterus. Journal of Reproduction and Fertility 92 393-406.

Shinohara K, Tominage K, Isobe Y \& Inouye S-IT 1993 Photic regulation of peptides located in the ventrolateral subdivision of the suprachiasmatic nucleus of the rat: daily variations of vasoactive intestinal polypeptide, gastrin-releasing peptide, and neuropeptide Y. Journal of Neuroscience 13 793-800.

Spindel ER, Sunday ME, Hofler H, Wolfe HJ, Habener JF \& Chin WW 1987 Transient elevation of mRNA encoding GRP, a putative pulmonary growth factor in human fetal lung. Journal of Clinical Investigation 80 1172-1179.

Stjernquist M, Ekblad E, Owman C \& Sundler F 1986 Neuronal localization and motor effects of gastrin-releasing peptide (GRP) in rat uterus. Regulatory Peptides 13 197-205.

Wathes DC, Mann GE, Payne JH, Riley PR, Stevenson KR \& Lamming GE 1996 Regulation of oxytocin, oestradiol and progesterone receptor concentrations in different uterine regions by oestradiol, progesterone and oxytocin in ovariectomized ewes. Journal of Endocrinology 151 375-393.

Westendorf JM \& Schonbrunn A 1982 Bombesin stimulates prolactin and growth hormone release by pituitary cells in culture. Endocrinology 110 352-358.

Whitley J, Giraud A, Salamonsen L, Grant P \& Shulkes A 1994 Expression of gastrin-releasing peptide during pregnancy. Proceedings of the 37th Annual Meeting of the Endocrine Society of Australia, Abstract 55. Brisbane: Endocrine Society of Australia.

Whitley JC, Giraud AS \& Shulkes A 1996 Expression of gastrinreleasing peptide (GRP) and GRP receptors in the pregnant human uterus at term. Journal of Clinical Endocrinology and Metabolism $\mathbf{8 1}$ 3944-3950.

Whitley JC, Shulkes A, Salamonsen LA, Vogiagis D, Familari M \& Giraud AS 1998 Temporal expression and cellular localization of a gastrin-releasing peptide-related gene in ovine uterus during the oestrous cycle and pregnancy. Journal of Endocrinology 157 139-148.

Whitley JC, Moore C, Giraud AS \& Shulkes A 1999 Molecular cloning, genomic organization and selective expression of bombesin receptor subtype 3 in the sheep hypothalamus and pituitary. Journal of Molecular Endocrinology 23 107-116.

Zachary I \& Rozengurt E 1985 High affinity receptors for peptides of the bombesin family in Swiss 3T3 cells. PNAS 82 7616-7620.

Received 7 February 2000

Accepted 4 May 2000 